\title{
The Thetford Treasure
}

\section{A MAJOR FIND OF LATE ROMAN GOLD AND SILVER}

\section{Catherine Johns}

The British Museum, London, U.K.

At the end of 1979, a group of gold and silver objects dating to the end of the 4 th century A.D. was found buried near Thetford, Norfolk, in eastern England. Under British law, gold and silver found in the ground must be declared to the authorities, and if the appropriate court of law decides that the unknown original owner buried them for safety, hoping to retrieve them, they are declared to be Treasure Trove and the property of the Crown. In the case of objects of archaeological importance, this means in practice that they will be acquired by a museum. Though there were some delays in the case of the Thetford treasure, it was eventually declared Treasure Trove in February 1981, and, at the time of writing, is under study at the British Museum. In due course, a full scholarly catalogue of this extremely important discovery will be published.

The treasure consists of two groups of material, gold jewellery and silver tableware. The jewellery comprises a belt-buckle, twenty-two rings, four bracelets and several pendants, earrings and necklaces. Both gold and silver objects are in outstandingly good condition and comparison with other dated finds indicates that they must have been buried at the end of the 4 th century or the very beginning of the 5 th, during which period Britain finally ceased to be a part of the Roman Empire.

A particularly important feature of the find is the inscription of names and phrases on nearly all of the silver spoons. An ancient pagan Italian god, Faunus, is invoked in many of these inscriptions, and his name is combined with by-names or epithets of Celtic, not Latin, form. This implies worship of Faunus in Britain or Gaul (both Celtic-speaking areas) at a time when the Roman Empire was officially Christian. It is known that paganism was still very strong at this time, but archaeological evidence for the worship of Faunus is extremely rare, and the Thetford find is therefore of prime importance in the study of the religious history of the Roman world.

\footnotetext{
The gold belt-buckle which is the most striking item in the find, decorated with horses' heads and a dancing satyr. The tongue of the buckle is missing. The rectangular plate on which the satyr is separately cast is $5.2 \times 2.8 \mathrm{~cm}$ in size Photograph by courtesy of the Trustees of the British Museum
}

The gold objects are visually the most striking items, and they are all illustrated here. Probably the most magnificent is the belt-buckle with a bow formed of two confronted horses' heads and a rectangular plate decorated in relief with a dancing satyr holding aloft a bunch of grapes. The rings, all but one for a female rather than a male hand, are in typically lateantique taste, utilizing coloured settings - amethysts, nicolo, garnets, emeralds and glass - in elaborate and richly textured mounts. Some of the rings have engraved ornament on the shoulders, while several have intricate patterns applied in gold wire and tiny globules; three have shoulders shaped in the form of animals, dolphins in two cases and birds in the other. The fine engraved gems were almost certainly re-used from earlier jewellery, a frequent practice in the 4th century, when gem-engraving was a vanishing art. Two of the rings have hoops in a very unusual pattern reminiscent of basket-work, and this is also used in the matching pair of bracelets. Another bracelet, though fairly plain, is the heaviest single item in the treasure. The necklaces are of the fine 'plaited' wire which was popular throughout the Roman period and indeed even in Greek times. One has green glass beads and another has a clasp in the form of serpents' heads. Some of the jewellery was found in a round trinket-box made of shale, a slate-like material.

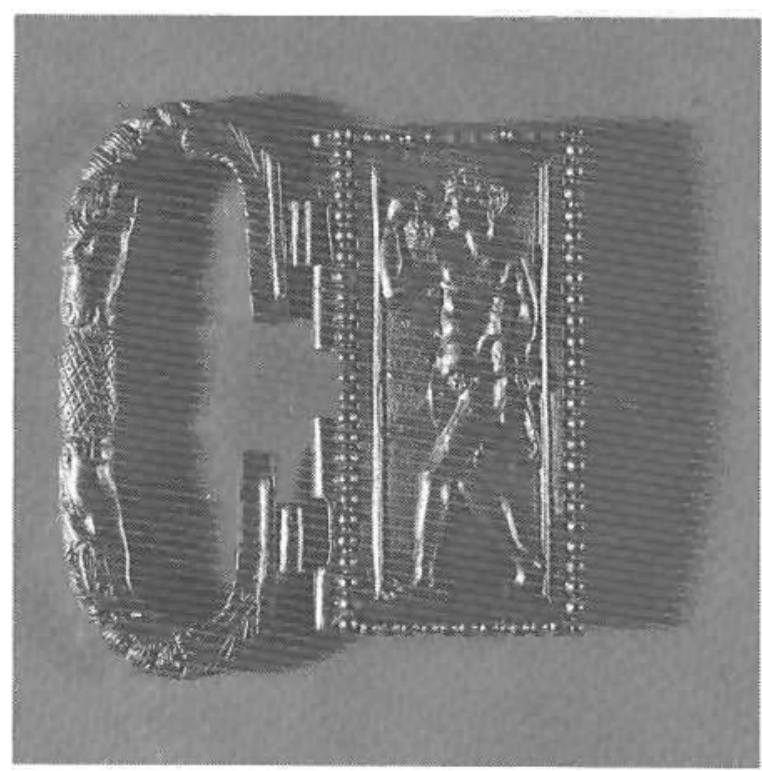




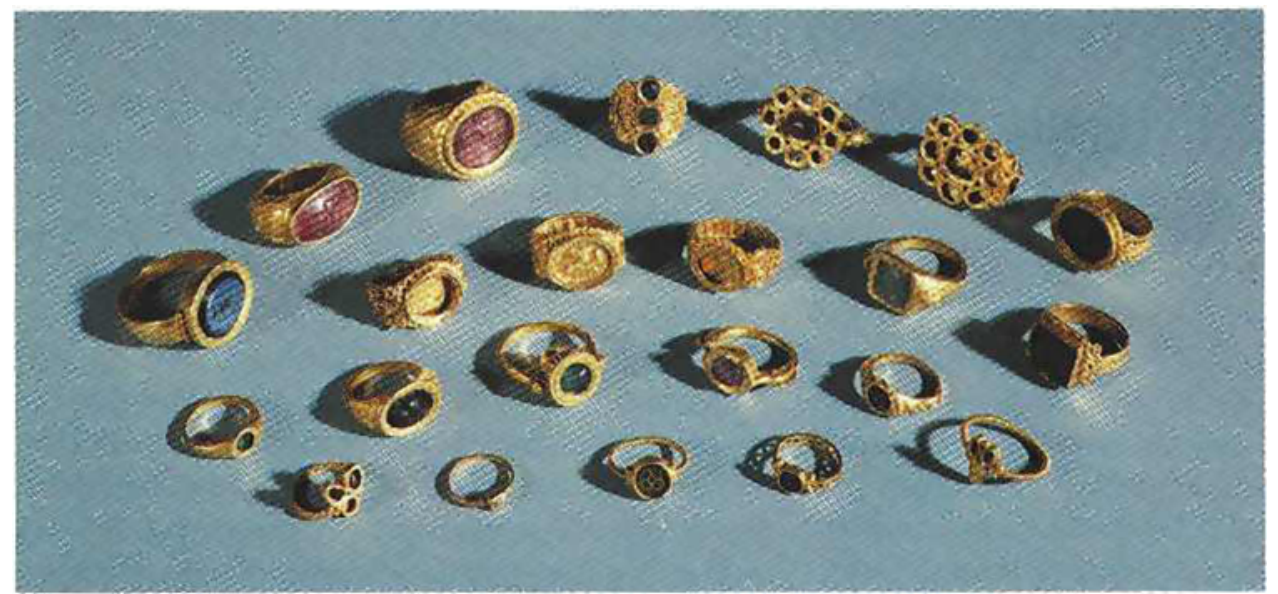

The twenty-two gold finger-rings from the Thetford treasure, many containing coloured stone settings which richly complement the elaborate and intricate patterns in the mounts Photograph by courtesy of the Trustees of the British Museum

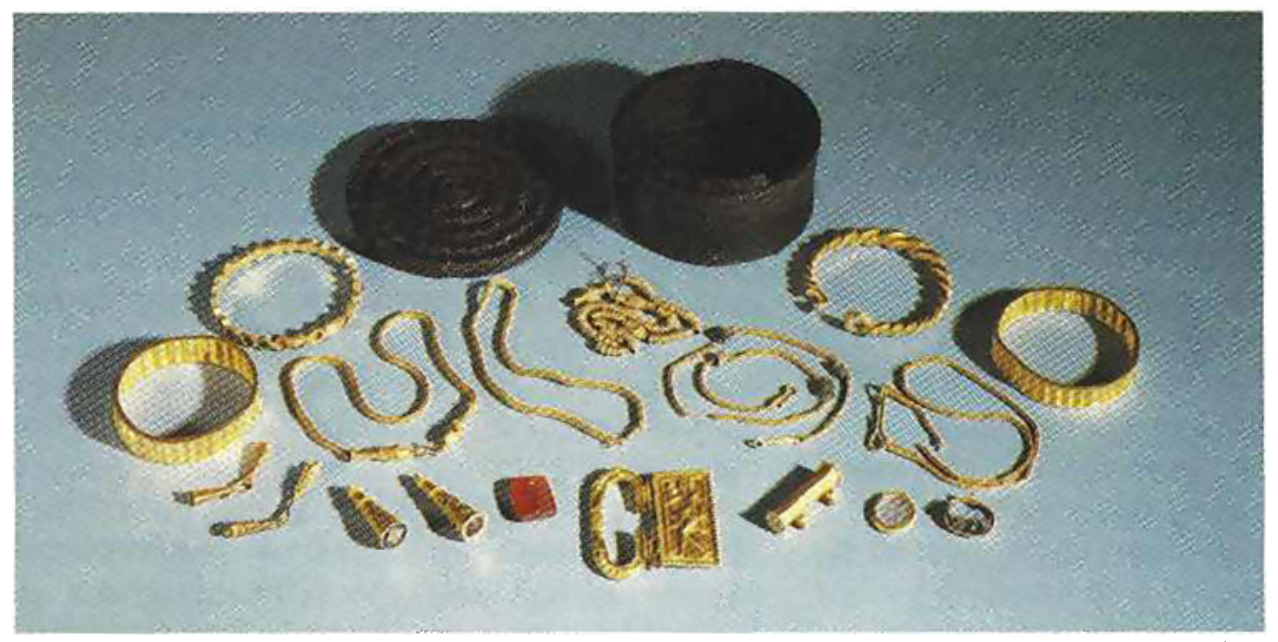

The different items of gold jewellery from the Thetford find, excluding the rings, shown together with the shale trinket box which contained some of the objects when unearthed Photograph by courtesy of the Trustees of the British Museum

There are three factors about the jewellery which lead to a very important conclusion. First, the objects are made, like most Roman gold ornaments, from gold of very high purity (about 94 to 96 per cent), yet they show practically no sign of wear. Secondly, there is some evidence that some pieces, like the odd necklace clasps and one unmounted gem (a splendid carnelian depicting Venus and Cupid), may be unfinished. Finally, there are so many stylistic affinities throughout the group, like the rare zoomorphic rings and the 'basket' pattern, that it must be concluded that the find consists of the products of a single jeweller or jewellery workshop. It appears as though the Thetford jewellery was the unsold stock-in-trade of a craftsman of the late Roman period.

As yet, little can be said about the precise relationship between the gold and the silver objects, beyond the fact that they were certainly buried together. How they came to be in this part of Britain is a particularly intriguing question, since there can be no doubt that the jewellery was made in another province of the Empire, perhaps Gaul, or even further afield. There is already ample evidence for wealth in late Roman Britain, demonstrated by finds such as the Mildenhall treasure of 4th century silver tableware, found about forty years ago in an area not very far from Thetford. The unsettled conditions in Britain towards the end of Roman rule meant that the burial of valuables for safety was a common practice. Perhaps the owner of the Thetford material hoped to find among the wealthier citizens of Roman Britain a market for his expensive wares, though the intrinsic value and the artistic quality of his products would have been very exceptional anywhere in the Empire.

There are many questions to be answered and much work still to be done, but we already know that the Thetford treasure must rank as one of the major Roman discoveries of the century. 